\title{
ANALYSIS OF HEAVY METALS IN WATER AND FISH CIRRHINAMRIGALA OF RIVER GODAVARI, AT NATHSAGAR DAM IN MAHARASHTRA, INDIA
}

\author{
M. J. Shaikh \\ Department of Zoology, Arts, Commerce \& Science College, Sonai, Maharashtra, India \\ Corresponding Author: mjshaikh1850@gmail.com \\ Communicated: 25.02 2020 Revision:10.03.20 \&19.04.2020 \\ Accepted: 20.05 .2020 \\ Published: 30.05 .2020

\begin{abstract}
The concentrations of heavy metals $(\mathrm{Cd}, \mathrm{Cr}, \mathrm{Pb}, \mathrm{Ni}$ and $\mathrm{Zn}$ ) in sample water and organs (muscle, gills and liver) of fish Cirrhinamrigala of river Godavari, at Nathsagar Dam in Maharashtra were analyzed. There was an appreciable decrease in metal concentrations in sample water from site I to site II. The heavy metal concentrations in sample water was in the order $\mathrm{Ni}>\mathrm{Pb}>\mathrm{Cd}>\mathrm{Zn}>\mathrm{Cr}$. Accumulation of heavy metals in the organs of fish Cirrhinamrigala was found in the order gills $>$ muscle $>$ liver. In the gills, lead was found maximum (3.83 $\mu \mathrm{g} / \mathrm{g}$ dry weight), whereas chromium was minimum $(0.68 \mu \mathrm{g} / \mathrm{g}$ dry weight). In the muscles, the values of lead was $2.59 \mu \mathrm{g} / \mathrm{g}$, comparatively chromium was $0.64 \mu \mathrm{g} / \mathrm{g}$. In the liver, lead, cadmium and nickel were more concentrated compared to zinc and chromium. The concentration of heavy metals accumulated in gills and liver was found in the order $\mathrm{Pb}>\mathrm{Cd}>\mathrm{Ni}>\mathrm{Zn}>\mathrm{Cr}$ and in the muscles, it was found in the order $\mathrm{Pb}>\mathrm{Cd}>\mathrm{Ni}>\mathrm{Cr}>\mathrm{Zn}$. As the fish Cirrhinamrigala is largely consumed by people, it is essential to make awareness about water pollution and effects of heavy metals on human body.
\end{abstract}

Keywords: Heavy metals, Cirrhinamrigala, fish organs, Godavari River, Nathsagar dam.

\section{INTRODUCTION:}

The pollution of aquatic environment by inorganic and organic chemicals is a major factor posing serious threat to the survival of aquatic organisms including fish. Among the environmental pollutants, metals are of particular concern due to their potential toxic effect and ability to bioaccumulate in aquatic ecosystems. The presence of heavy metals in aquatic ecosystem is the result of two main sources of contamination; natural processes and anthropogenic activities. Heavy metals including both essential and non-essential elements have a particular significance in ecotoxicology, since they are highly persistent and all have the potential to be toxic to living organisms (Adeniyi and Yusuf, 2007).

Fish is often at the top of aquatic food chain and may concentrate large amounts of some metals from the water. Metal bioaccumulation is largely attributed to differences in uptake and depuration period of various metals in different fish species. Multiple factors including season, physical and chemical properties of water can play a significant role in metal accumulation in different fish tissues. The gills are directly in contact with water. Therefore, the concentration of metals in gills reflects their concentration in water where the fish lives, whereas the concentration in liver represents storage of metals in water (A.Rauf et al., 2009). Fishes are notorious for their ability to concentrate heavy metals in their muscles and since they play important role in human nutrition, they need to be carefully screened to ensure that unnecessary high level of some toxic trace metals are not being transferred to man through fish consumption.

The present research work aimed to analyze the accumulation of heavy metals (Cadmium, Chromium, Lead, Nickel and Zinc) in water and fish organs of Cirrhinamrigala, of river Godavari at Nathsagar Dam from Maharashtra. 


\section{MATERIALS AND METHODS:}

Water samples and fish samples (Cirrhinamrigala) were collected from two different sites of river Godavari in August 2014. Site I was near the Nathsagar Dam and Site II was $2 \mathrm{Km}$ away from Dam, at upstream water of river Godavari. Water samples were collected in the middle of the river at $50 \mathrm{~cm}$ below the surface, using 1 liter polythene bottles with screw caps. The bottle had been washed and soaked in 5\% nitric acid and rinsed with deionised water before use. The water samples were acidified immediately after collection by adding $5 \mathrm{ml}$ nitric acid to minimize adsorption of heavy metals onto the walls of the bottles (APHA, 1998). Water samples were analyzed in Atomic Absorption Spectrophotometer for detection of heavy metals.

Samples of five fish (Cirrhinamrigala) of nearly equal size and weight were dissected to remove muscles, gills and liver. The separated organs were put into petri dishes to dry at $120^{\circ} \mathrm{C}$. The organs were placed into digestion flasks and ultrapure Con. Nitric acid and hydrogen peroxide $(1: 1 \mathrm{v} / \mathrm{v})$ was added. The digestion flasks were then heated to $130^{\circ} \mathrm{C}$ until all the materials were dissolved. Digest was diluted with double distilled water appropriately. The heavy metals $\mathrm{Cd}, \mathrm{Cr}, \mathrm{Pb}, \mathrm{Ni}$ and $\mathrm{Zn}$ were assayed using Atomic Absorption Spectrophotometer and the results were given as $\mu \mathrm{g} / \mathrm{g}$ dry weight. Data obtained from the experiments were analyzed and the results were expressed as mean of all five. Values of $\mathrm{P}<0.05$ were considered statistically significant.

\section{RESULTS AND DISCUSSION:}

Average heavy metal concentrations in the sample water collected from two sites of Nathsagar Dam is given in Table - 1. The traces of heavy metals in water was found to decrease in the sequence $\mathrm{Ni}>\mathrm{Pb}>\mathrm{Cd}>\mathrm{Zn}>\mathrm{Cr}$ at both the sites. Maximum amount of metal found in sample water was nickel. The values of nickel observed were $7.53 \mu \mathrm{g} / 1$ at site I and $5.80 \mu \mathrm{g} / 1$ at site II. The values of chromium were minimum $1.23 \mu \mathrm{g} / 1$ at site II and $1.7 \mu \mathrm{g} / 1$ at site I. The higher level of lead, cadmium and zinc in the river water may be due to excessive use of pesticides and fertilizers in the agriculture fields along the banks of this river.

The analysis of heavy metals in different organs of fish Cirrhinamrigala is shown in Table - 2. All the three organs - muscle, gills and liver shows different values of accumulation of heavy metals. Gills show higher level of metals succeeded by muscle and liver. In the gills, the sequence of trace metals is $\mathrm{Pb}>\mathrm{Cd}>\mathrm{Ni}>\mathrm{Zn}>\mathrm{Cr}$. It is observed that the sequence of trace metals is $\mathrm{Pb}>\mathrm{Cd}>\mathrm{Ni}>\mathrm{Cr}>\mathrm{Zn}$ in muscles and $\mathrm{Pb}>\mathrm{Cd}>\mathrm{Ni}>\mathrm{Zn}>\mathrm{Cr}$ in liver. The concentration of zinc and chromium shows fluctuations in all the three organs. The maximum amount of metals found in fish organs is lead, accumulating the gills. It shows values $3.83 \mu \mathrm{g} / \mathrm{g}$ dry weights at site I and $3.35 \mu \mathrm{g} / \mathrm{g}$ dry weights at site II. The values and sequence of heavy metals found in different organs are correlated with the results found by Abida Begum et al., 2009. Accumulation of bioactive metals like cadmium, chromium, lead, nickel and zinc was actively controlled by fish through different metabolic processes and the level of accumulations usually depend on ambient concentrations. In the literature, heavy metal concentration in the tissues of freshwater fish vary considerably among different studies (Chattopadhyayet al., 2002; Papagianniset al., 2004), possibly due to chemical characteristics of water, ecological needs, metabolism and feeding patterns of fish.

\section{CONCLUSIONS:}

The results of this study supply valuable information on the metal contents in water 
sample and fish organs of the river Godavari, at Nathsagar Dam. Fish gills and muscles shows highest tendency to accumulate both lead and cadmium, while accumulation of metals is less in liver. As the fish Cirrhinamrigala is one of the main aquatic food, it should be noticed by the consumers and awareness must be done.

\section{ACKNOWLEDGEMENTS:}

The author acknowledges sincere and heartfelt thanks to B.C.U.D., University of Pune for sanctioning a minor research project for this research work. He is also thankful to Principal, Arts, Commerce and Science College, Sonai for providing necessary laboratory facilities.

\section{REFERENCES:}

Abida Begum, Hari Krishna S. and Irfanulla Khan, 2009. Analysis of heavy metals in water, sediments and fish samples of Madivala lakes of Bangalore, Karnataka. Int. J.ChemTechRes., 1(2) : 245-249.

Adeniyi, A.A. and K.A.Yusuf, 2007. Determination of heavy metals in fish tissues, wter and bottom sediments from Epe and Badagry Lagoons, Lagos, Nigeria.Environ. Monitor.Assess., 37 : 451-458.

Table - 2: Average heavy metal concentrations ( $\mu \mathrm{g} / \mathrm{g}$ dry weight) in different organs of fish

\begin{tabular}{|c|c|c|c|c|c|c|c|c|c|c|}
\hline \multirow{2}{*}{ Organ } & \multicolumn{9}{|c|}{ Site I } & \multicolumn{5}{c|}{ Site I } \\
\cline { 2 - 12 } & $\mathbf{C d}$ & $\mathbf{C r}$ & $\mathbf{P b}$ & $\mathbf{N i}$ & $\mathbf{Z n}$ & $\mathbf{C d}$ & $\mathbf{C r}$ & $\mathbf{P b}$ & $\mathbf{N i}$ & $\mathbf{Z n}$ \\
\hline Muscle & 2.31 & 0.73 & 2.59 & 1.92 & 0.59 & 2.07 & 0.64 & 2.24 & 1.85 & 0.51 \\
\hline Gills & 2.90 & 0.85 & 3.83 & 2.72 & 1.36 & 2.76 & 0.68 & 3.35 & 2.60 & 1.18 \\
\hline Liver & 1.43 & 0.37 & 1.70 & 1.17 & 0.48 & 1.37 & 0.34 & 1.46 & 1.04 & 0.39 \\
\hline
\end{tabular}

APHA (American Public Health Association), 1998.Standard methods for examination of water and waste water.20th Edition, New York, USA.

A.Rauf, M.Javed and M.Ubaidullah,2009. Heavy metal levels in three major carps (Catlacatla, Labeorohita and Cirrhinamrigala) from the river Ravi, Pakistan. Pakistan Vet. J., 29(1): 24-26.

Chattopadhyay, B., A.Chatterjee and S.K.Mukhopadhyay,2002.Bioaccumulati on of metals in East Calcutta wetland ecosystem.Aquat.Ecosys. Health Manag., 5(2) : 191-203.

Papagiannis, I., I.Kagalou, J.Leonardos, D.Petridis and V.Kalfakaou, 2004. Copper and zinc in four freshwater fish species from Lake Pamvotis (Greece). Environ. Int., 30 : 357-362.

Table - 1: $\begin{gathered}\text { Average } \\
\text { heavy }\end{gathered}$
$\begin{gathered}\text { metal } \\
\text { concentrations }(\boldsymbol{\mu g} / \mathbf{1})\end{gathered}$ in \begin{tabular}{c|c|} 
sample \\
water
\end{tabular}
collected from two sites of Nathsagar Dam
\begin{tabular}{|c|c|c|}
\hline Heavy metal & Site I & $\begin{array}{c}\text { Site } \\
\text { II }\end{array}$ \\
\hline $\mathbf{C d}$ & 4.79 & 3.65 \\
\hline $\mathbf{C r}$ & 1.70 & 1.23 \\
\hline $\mathbf{P b}$ & 6.26 & 5.12 \\
\hline $\mathbf{N i}$ & 7.53 & 5.80 \\
\hline $\mathbf{Z n}$ & 3.20 & 3.47 \\
\hline
\end{tabular}

\section{Cirrhinamrigala collected from Nathsagar Dam \\ Table - 2: Average heavy metal concentrations (ug/g dry weight) in different organs of fish}

